\title{
The Development trend of castles in Andimeshk Zone during historical and Islamic periods
}

\author{
Kazem Shahavand ${ }^{1}$, Dr. Seyed Ali Asghar Mir FatTaH ${ }^{2}$, Dr. Mohammad BAHRAmZAdeH ${ }^{3}$ \\ 1. MA Student in the Field of Archeology, Abhar Branch, Islamic Azad University, Abhar, Iran \\ 2,3. Assistant Professor in Group of Archeology, Abhar Branch, Islamic Azad University, Abhar, \\ Iran \\ The present essay is excerpted from MA thesis
}

\begin{abstract}
Andimeshk is one of the cities with several archeological buildings and monuments and it represents quantitatively and qualitatively a type of local and regional architecture belonging to historical and Islamic period. The castles are some of these monuments so that it has been tried in this essay to define the position of their architectural structure with study on the castle during historic and Islamic periods. According to objectives in this investigation, initially some issues have been examined and studied including geographic and historic position, typology, and their architectural importance and features and the buildings in terms of architectural structure and porcelains and materials and eventually it has been concluded that there are 9 castles in Andimeshk geographic zone. Construction of Lour, Gasem, Chalat, and Mongareh castles belongs to Sassanid (historic) period. Two Chalat and Mongareh castles have been employed as two very important security citadels in Islamic periods during Seljuk Dynasty and repeatedly during Ilkhanate Era. But two zones of Lour and Gasem castles have been inhabited again during Ilkhanate Dynasty while Sarqala or Amir Seif castle, which its building was formed primarily during Ilkhanate period, would be probably concurrent with aforesaid castles. Early formation of Hosseini, Chehar Borji (four towers), Bardel, and Couran (Kooru) castles belongs to Safavid period, which has been built by Luristan rulers and repaired during Qajar Dynasty.
\end{abstract}

Keywords: Castles, Regional Climate, Historic and Islamic period, Andimeshk.

\section{Introduction}

The security has been deemed important for the human in ancient time and security and defensive role has been noticed by humans in their habitat since date of their cave-dwelling. Defensive structures, which have been built by humans to protect from their own against invasion and for security purpose during history, are introduced under several titles like castle, citadel, fortress, city stronghold, and village bastion ands... where each of which has certain specifications and definitions. During several historic periods, these defensive fortifications had various applications and certain features and several factors have played role in their building. Of these factors one can refer to some points including attack by wild animals, invasion by aliens, and proximity to religious and ruling centers, having the common border with other governments and some similar agents like this. One of the important cases, which have been crucial in building of these castles, was their role 
in establishing security for access routes and the connection paths, which have been especially noticed from ancient time to Islamic period (Zarei, 2013:343).

The castles belonging to historic and Islamic periods spread throughout Iran and in general they have been built along the connection arteries out of these types one can refer to the castles in Andimeshk Town, which have been constructed to guard the roads and establishment of security through the path of caravan passing roads as well as providing the welfare and security for the inhabited people in the given zone.

With respect to climatic and geographic conditions in Andimeshk as well as its location among two provinces i.e. Khuzestan and Luristan, one can examine well the developing trend of castles and their importance in this region during historic and Islamic period. Andimeshk has been considered as one of the important communication centers in Luristan and Khuzestan throughout all historic and Islamic periods and the inhabitant people had to build public habitats in northern district (Bakhshe Alvar) on heights and mountains and often within the inter- mount plains and sometimes in the deserted flats in order to protect and guard the caravan passengers and pilgrims to defend them against invasions by regional and trans-regional tribes. The presence of many castles in this region indicates this fact and their architectural artifacts are evident for this issue. One may refer to some of important castles, which have also acted as a ruling headquarter rather than playing security role including Dez Castle (Mongareh), Lour castle, Couran castle (Kooru).

\section{Geographic situation of Andimeshk town}

Andimeshk town is situated at north of Khuzestan province on southern piedmonts of Luristan province (Iran) and $158 \mathrm{~km}$ distant from the northern side of Ahwaz city. It is at neighborhood with Dezful from the east, with Susa at south, and with Abdanan in Ilam province from the west, and with Poldokhtar and Khorramabad in Luristan at north. The geographic coordinates of this town are as follows: It is located on eastern longitude (48 $\left.21-22^{\prime}\right)$ in respect of Greenwich Meridian and in northern latitude of $\left(32^{\circ}, 27^{\prime}\right)$ from the equator. Andimeshk town is located on the plateau and even zone of Khuzestan province and it enjoys temperate and also hot and dry (tropical) climate (Villages geographic glossary: 30) (Archives of Iranian Cultural Heritage and Tourism and Handicraft Organization (ICHTO) Andimeshk City).
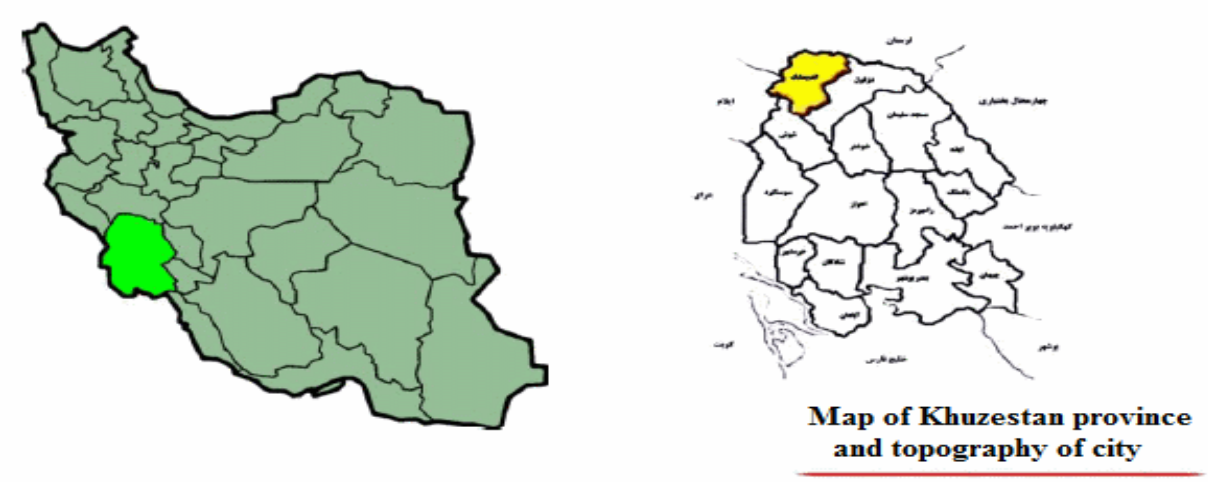

Fig 1: Geographic situation of Khuzestan and Andimeshk town (Sources: Archives (ICHTO) Organization, Andimeshk City) 


\subsection{Lour Castle}

This castle is situated on northern part of Andimeshk today town in a region that is called Gela (castle) and $5 \mathrm{~km}$ distant from Andimeshk town. The historians have frequently implied this region for several times in early centuries of Islamic period although at present there is track of eight door castle (Hasht Dar), some remained tracks can be seen so far from the architectural structures of Lour City in one kilometer distant from the south of Qotb Castle near to water channel. It is narrated that lour Castle has been built by Seyed Hossein Qotb (well-known as Abreh) so it has been put at disposal of his children and grandchildren after him. After Islamic Revolution in Iran, title of Qotb Castle was changed into Lour Castle and eventually it was ruined over the time due to lack of preservation and protection after 1991 (Archives of ICHITO Organization, Andimeshk Town).

\subsection{Gasem Castle}

It is found several ancient and artifacts and monuments with historical backgrounds at northern part of Andimeshk Town in southwestern side of Tangovan mount near to Cole Mahak Station that is well-known as Gasem Castle. Tangovan Mount is situated at the front of DuKuhe Garrison.

The tracks of water transfer system are identified on the piedmont of Tangovan Mount thus at present total zone is currently encompassed by Islamic Revolutionary Guard Corps (IRGC) so the author of this essay could not receive any permission to deal with his field study in the given zone in order to prepare an accurate report from its precise situation and architectural structure. According to quotation from the report of ICHTO Organization, this historical castle and its monuments, which are situated around this area, have been built during the rule of Arabs namely they are assumed as historic monuments at post-Islamic era. It seems that around the aforesaid castle several fences and channels have been constructed as well for water collection in which the needed materials are rock and lime-ash grout (Sarouj) for their building. Anyway, this castle is considered as one of old and historic castles in this area (Archives of ICHITO Organization, Andimeshk Town). In the book of "Luristan ancient and historic monuments", Izadpanah has referred to Bard Pale in Tangovan Mount (Izadpanah, 1997:10). But, he has published no report regarding Gasem Castle.

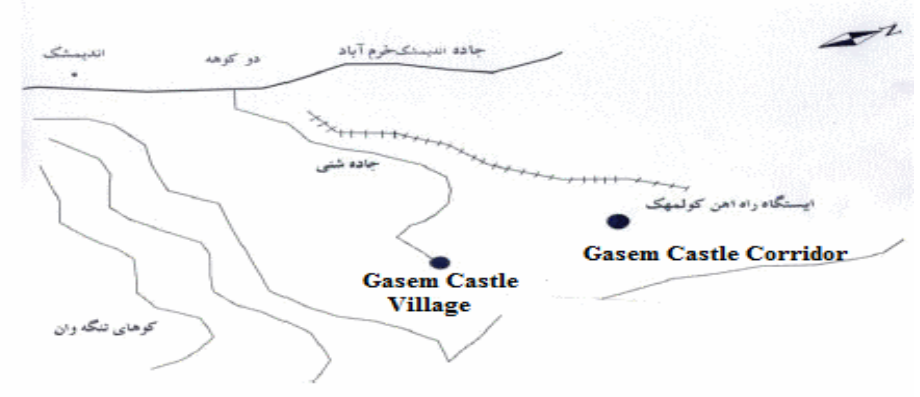

Fig 2: Scheme of Gasem Castle Zone

(Source: Archives of ICHITO Organization, Andimeshk Town) 


\subsection{Chehar Borji Castle}

This castle is situated in Andimeshk- Poldokhtar Road and exactly located in Today Hosseini City at eastern side and approximately $70 \mathrm{~m}$ distant from asphalted road. Namely, it is located within today zone of military base and Jihad- Agriculture Organization. This castle has been constructed in four sides with quadrangular plan and its area is totally $500 \mathrm{~m}^{2}$. It includes four circular towers in its four corners so that over the time two towers have been destroyed in this castle and only two towers have remained sound at its eastern side. The monument has been built with several materials including rubble, brick, and raw adobe, and plaster and lime grout.

According to narration from Hamid Izadpanah, this castle is situated in the path of caravan passengers from Luristan to Khuzestan and technique of construction and building of this castle was similar to Raze Castle. This castle has been constructed during Safavid era by the order of Hossein Khan Ruler (the first ruler of Poshtkuh) and it has been later used by the inhabitants in this region so today only some pale tracks of this castle can be seen in this zone (Izadpanah; 1997:12). 5 porcelain artifacts have been extracted from this zone of castle out of which 3 objects were coated with green and green to aqua color enamel that was related to Islamic Mid Centuries (13 and $14^{\text {th }}$ AD) and two latter objects were coated with bright aqua colored enamel, which probably belonged to $14^{\text {th }}$ and $15^{\text {th }} \mathrm{AD}$ centuries. Hosseini Castle has been recorded as historic monument under registration no 29351 dated from Islamic Period (Safavid) in 2009 in Iran.
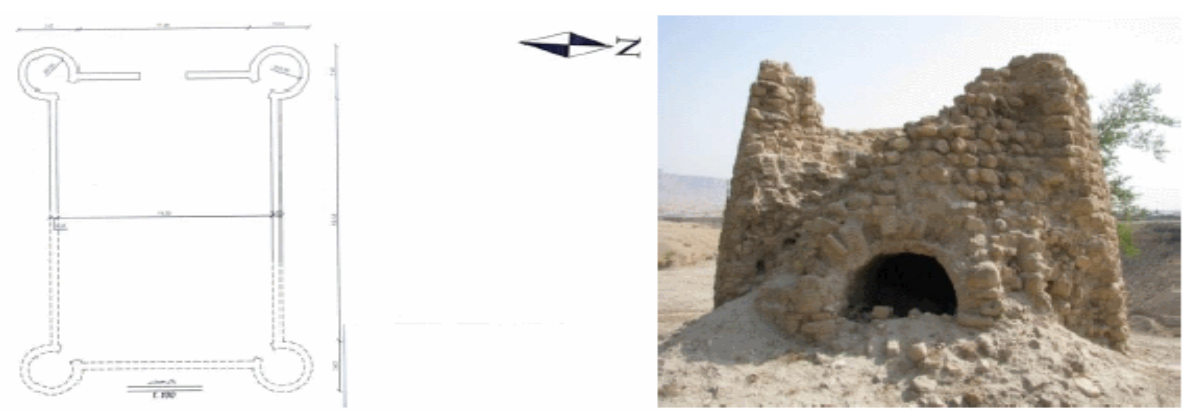

Fig 4: The remained plan and tower from Hosseini Castle

(Source: Author: June 2013)

\subsection{Hosseini Castle}

This castle is located on Andimeshk- Poldokhtar main road at 100m distant from north of Raze Castle and approximately 60km distant from northern side of Andimeshk Town.

This monument has been constructed with approximately square plan with a basement that has been destroyed and stuffed over the time. This military edifice has been used for guarding purpose on its date and it has been built on a rock hill in an area with dimensions $50 \times 50 \mathrm{~m}^{2}$. 


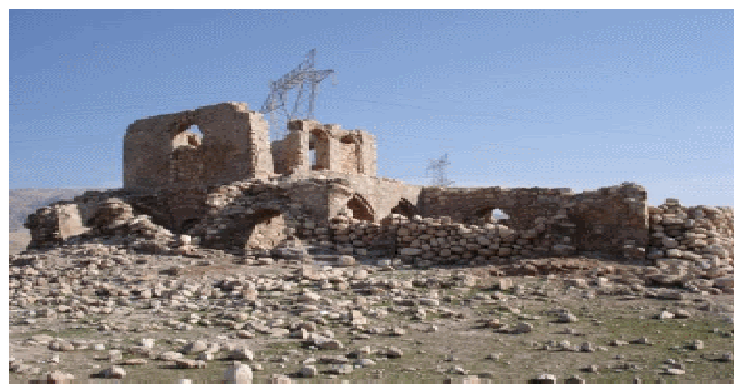

Fig 5: View of Hosseini Castle from the west side

(Source: Author, June 2013)

Castle building has been circumscribed with a fence made from cobble and lime where only a little part of this building has left from the past. It includes a central yard with two entrance gates where the main gate was built toward Raze Caravanserai (at south) and the latter gate was made toward the west. It comprises of 3 rooms on the floor in which some small and big size verandas have been installed there and generally several materials have been employed in this castle including cobble with rubble and plaster and lime mortar. The external fence of castle has been totally coated with lime grout and the interior rooms of the castle have been decorated and coated with plaster in a very beautiful way. According to a report from Hamid Izadpanah, this castle belongs to Safavid Era and it has been built by the order of Hossein Khan (Vali) Ruler (Izadpanah; 1997:16-17). Hosseini Castle has been recorded as a historical monument under registration no 18003 dated from Islamic Period (Safavid) in 2006.

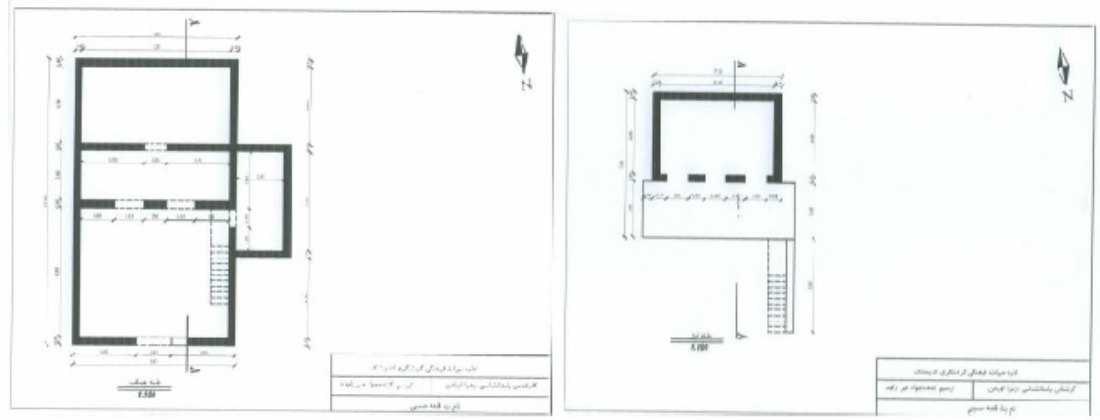

Fig 6: Plan of first storey and ground floor in Hosseini Castle (Source: Zahra Uramen; June 2013)

\subsection{Chalat- Qalache Castle}

It is located in 50km of Andimeshk- Mongareh Road in tropical Alvar District within Qilab County in a village called Chalat where there are several artifacts from an old castle that has been built with materials like rock, plaster, and lime. This castle is called Qalache (literally small castle) because according to opinion of the inhabitant people this is a small castle in this region. According to narration from the inhabitants in this village, the title of this village has been excerpted from name of castle (Chalat). The architectural structure of this building is composed of three residential areas, which have been interconnected together.

This building has been built with four sides and square plan with dimensions $(18 \times 18 \mathrm{~m})$. It comprises of two main gates where one of them is located at southern side and the other at west 
with $3.50 \mathrm{~m}$ width. It seems that one of them was provided for arrival and the other for departure but unfortunately their height is not identified because of collapse of walls. However, with respect to interior wall in one of the rooms, which have been relatively remained sound, the height of castle wall was $6 \mathrm{~m}$.

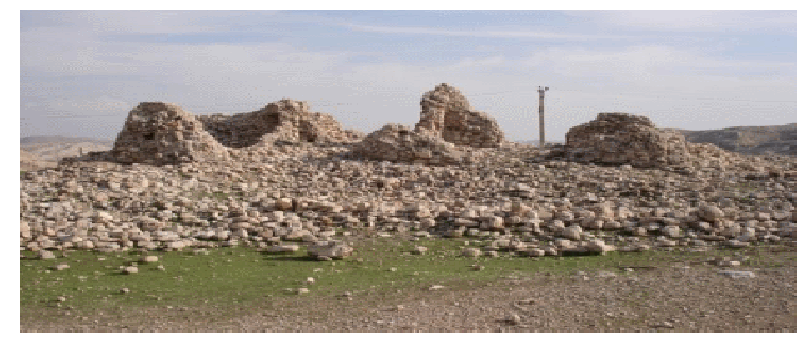

Fig 7: View of Chalat Castle at southern side

(Source: Author: June 2013)

I (author of this essay) sampled 18 porcelain artifacts from this zone out of them 7 objects have been coated with orange, mustard, and dark brown colored enamels and something like this and there was the engraved relief (with finger pressure sign) on one of these artifact and it probably belonged to Sassanid era and other 11 artifacts, which were coated with mustard and brown colored clay and light green, stripped green, green and beige, mustard yellow, and goldenrod pea colored as well as white enamels and also red goldenrod pea and brown coatings, belonged to Islamic early centuries so these artifacts were identified, photographed, and designed for this purpose. There is a mixture of lime mortar in historical porcelain artifacts containing red and mustard colored coating in walls at this monument that indicates Chalat Castle has been built in a historical zone (Sassanid) and it has been mainly noticed during the Islamic early periods, particularly $10^{\text {th }}$ AD century and this issue may be documented relatively with the found porcelains throughout this zone. Chalat Castle was recorded as a historical monument under no 18000 dated from historical era (Islamic early centuries) in 2006 .

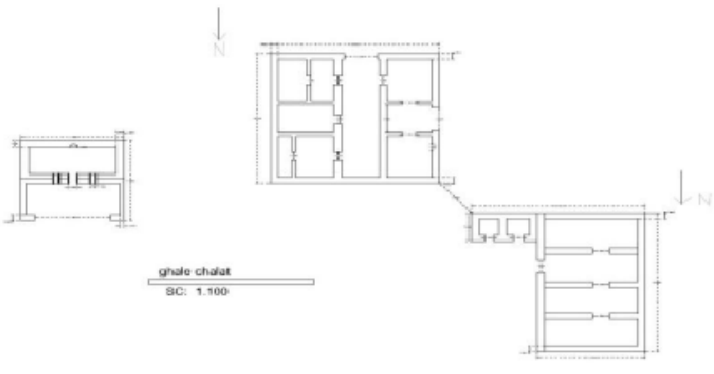

Fig 8: Plan of Chalat Castle

(Source: Author; June 2013)

\subsection{Amir Seif- Sarqala Castle}

Some tracks of an old castle remained in the region within Andimeshk- Mongareh Rod in Tropical Alvar District at Qilab County in a village that is called Amir Seif and it is well-known as Sarqala among rural inhabitants. This castle is located approximately 50km distant from Andimeshk Town. 

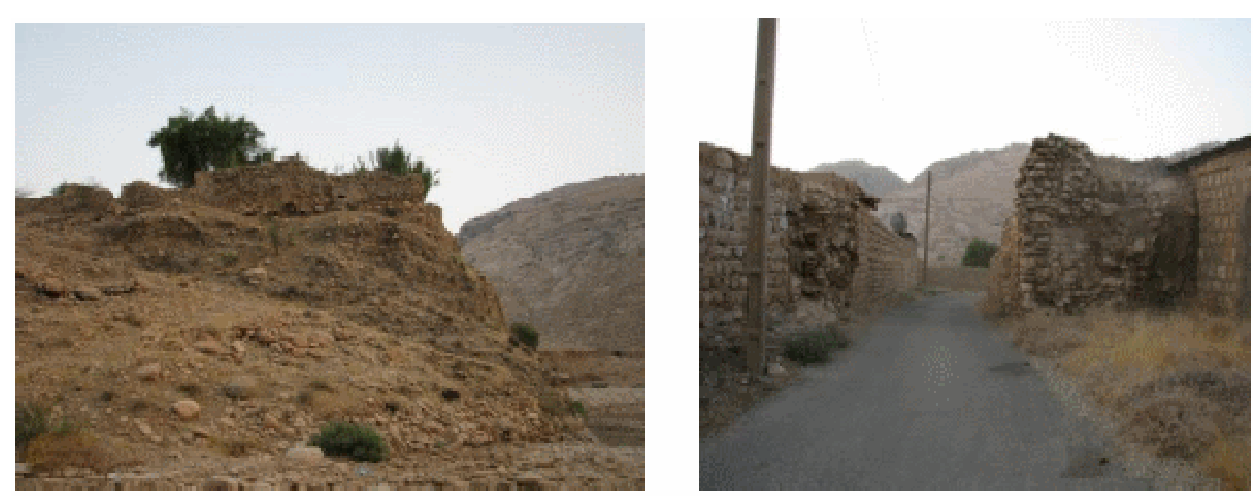

Fig 9: Entrance and view of fence of Amir Seif Castle at northern side

(Author: June 2013)

This castle that encloses the rural zone with irregular polygonal plan where it has been constructed with respect to natural situation of a hill on which it is located. The castle includes four circular towers out of which currently only one tower exists and this tower was destroyed to the half as well. Approximately one kilometer lower than this castle, there are some historical monuments of a castle in a village called Chalat and this castle is also well-known as Chalat (Qalache) and this may show that this path has been already considered as one of the important routes from Luristan to Khuzestan and assumed a very crucial area in terms of security and the people have noticed this area as an access route.

Hence, Amir Seif Castle (Sarqala) is one of those castles, which have used for security purpose and they were employed with respect to architectural style and the arches used in rooms, windows as well as arches which have been built in one of entrances in this castle probably belonged to $12^{\text {th }}$ and $13^{\text {th }}$ AD centuries. Hamid Izadpanah has described architectural structure of this castle in this way: "Dimensions of length and width of this tower are $200 \times 60 \mathrm{~m}$ where width of the wall is $3 \mathrm{~m}$. The west wall of this castle is pending to a valley with more than $30 \mathrm{~m}$ height through which Gerdab River passes from this valley and northern and eastern walls are also $10 \mathrm{~m}$ higher than ground level. The eastern wall includes a big gate that its path is ended to the level on the adjacent valley with a steep gradient. Dimension of this gate are $3.10 \times 2.40 \mathrm{~m}$. Also, the southern wall has a great gate that is remained currently with 2.80 height and 2m width." (Izadpanah; 1997: 15-16).

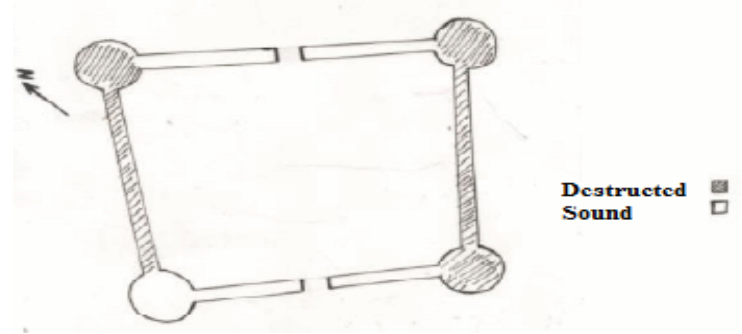

Fig 10: Plan of Amir Seif Castle (Sarqala)

(Source: Author; June 2013)

\subsection{Couran- Kooru Castle}

Couran or Kooru Castle is located in a region with the same name approximately $100 \mathrm{~km}$ distant from northern Andimeshk in the path of Bidrubeh- Emamzadeh (Shrine) Shahzadeh Ahmad in the tropical Alvar District. 

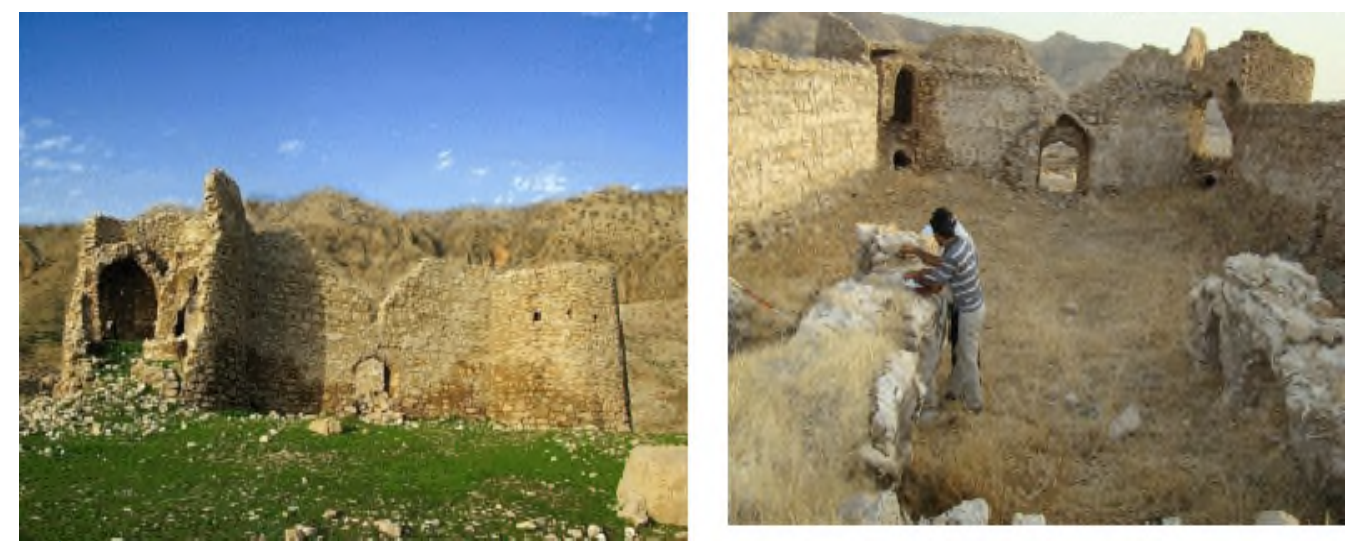

Fig 11: Interior and exterior views from Couran Castle at southern side

(Source: Author; April 2013)

Couran castle has been constructed according to a four sided and or quadrangular plan in northsouth direction. There are four towers on four corners of this castle out of them only three towers have so far remained and they have been built in three stories. It includes an entrance gate that is built toward south. According to Izadpanah remarks, although some parts of this castle have been destroyed the given castle so far remained intact and some people have already lived transiently in this castle. It seems that this castle, which has been made of stone and lime grout, belongs to the Islamic early periods. This castle has been mentioned in some of the noted manuscripts, which been left from trip of Shahzadeh Ahmad (Prince Ahmad) to Luristan and this may indicate that the aforesaid castle had been sound during nine AD century. In any case, this castle is one of the historical castles, which have enjoyed and currently enjoy special title and repute (Izadpanah; 1997: 19). Dimensions of its walls are as follows: wall in northern side $10.75 \mathrm{~m}$, wall locating at southern side $(9.30 \mathrm{~m})$, the wall situated at eastern side $(18.30 \mathrm{~m})$, and $19.20 \mathrm{~m}$ is the length of wall at western side. The castle comprises of four 3- storied towers at the four corners with $13.40 \mathrm{~m}$ external size of their diameter. Thus, only foundation of these towers is identified and its wall has been totally destroyed. The architectural style in this building is similar to the style of construction in Nasir Castel (Nasirqala) in Luristan. And at last this castle was recorded as historical monument under registration no 7149 as dated from Safavid era in National Organization of Registration of Monuments in 2002.

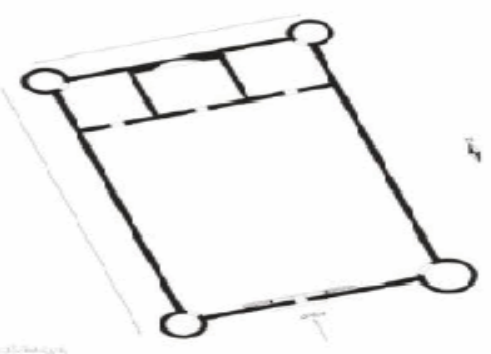

Fig 12: Couran (Kooru) Castle

(Source: ICHITO Organization, Andimeshk Town) 

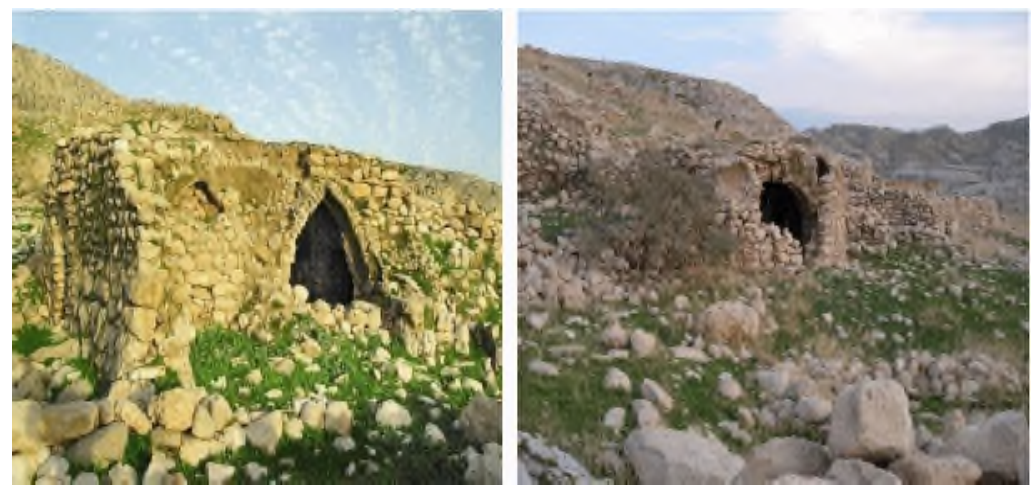

Fig 13: View from Bardel Castle Fences at southwestern side

(Source: June 2013)

This castle has been constructed on a gypsum hill pending to other surrounding areas with $300 \mathrm{~m}$ distant from Couran Castle. It comprises of the irregular polygonal plan that was built with respect to natural situation on the rock and it includes totally area of 5 hectares. The wall of rooms are 2.5 $\mathrm{m}$ high and several types of arches and vaults have been used in this building including zigzag arch, camber arch, barrel vault, saracenic arch, circular arch, and the like to cover ceilings, entrances, and verandas in this area and they have built with materials such as rubble and plaster and lime mortar. It is characterized from the architectural style and distribution of their effects that the given architectural structure belonged to a residential region so it is not similar to a castle but it has been known as a castle. In any case, since this construction is located beside Couran castle thus it enjoys appropriate and similar climatic conditions in respect of the aforesaid castle. Bardel Castle has been recorded as a historical monument dated from Safavid Era under n ${ }^{\circ} 17394$ in 2006.
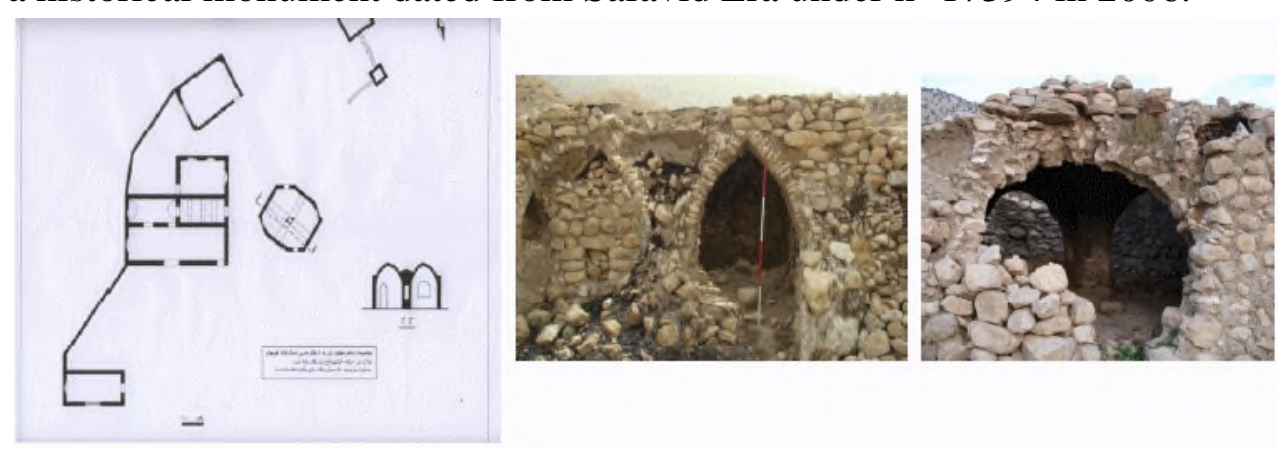

Fig 14: The used plan, arches, and vaults in Bardel Castle

(Source: Author, June 2013)

\subsection{Mongareh- Dez Castle}

Mongareh Castle is situated in 70km distant from north Andimeshk Town at Tropical Alvar District in Mongareh General Zone on peak of Dez Mount. Dez Mount on which this castle is placed with one thousand meters height and totally steep slope has been placed between Chavoni, Barikab, and Tokmuni mounts, which are placed in Zagros range. The area of this castle totally comprises of $15^{\prime} 000 \mathrm{~m}^{2}$ and generally the area in this castle has been built in such a way that its east wall is pending to Dez castle crag and the major parts of the surrounding regions and even farther areas can be seen well from its seeing site. 


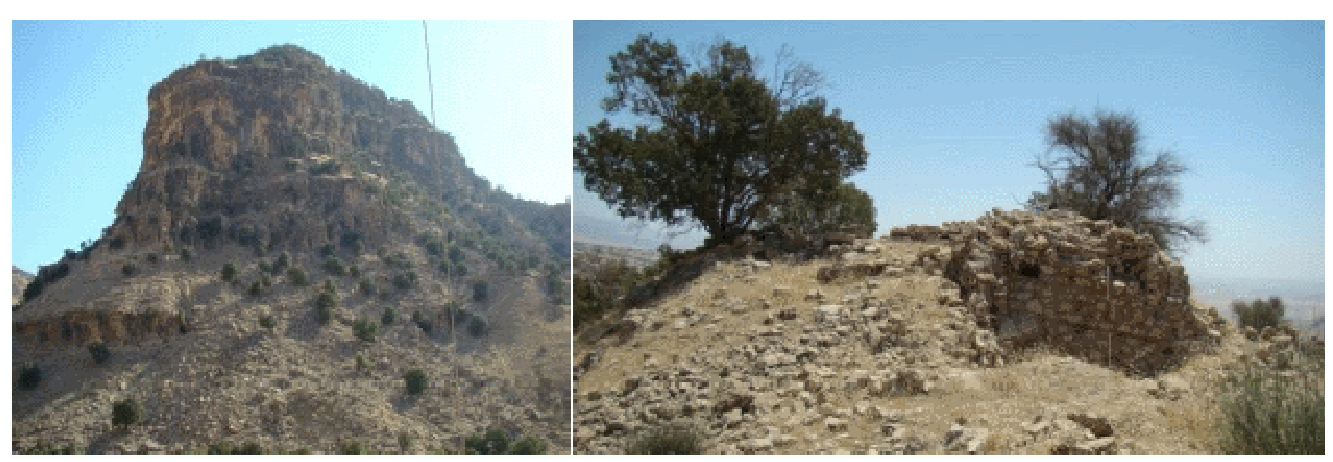

Fig 15: Dez Mount and architectural monument in Mongareh Castle

(Source: May 2013)

Mongareh Castle is especially important in terms of security and according to some narratives there was some conflict and dispute over its capture. Referring to Mongareh Castle as Mankarah, Hamdullah Mustofi, Persian historian, writes: “... Later caliphate headquarter called upon Shojaeddin Khorshid and his brother i.e. Nooreddin Mohammad and asked them to submit Mankarah Castle. They refused to do it so both of them were imprisoned. Nooreddin Mohammad was died in jail but he recommended his brother as the will that not to give that rock (castle) to them. Shojaeddin found that he could not get rid of jail without submittal the given castle. He asked the caliphate court to give him a property instead. They gave ruling in Tarazak as one of the affiliated counties in Khuzestan versus Mankarah Castle." (Mustofi; 1985:552) This manuscript from Mustofi may indicate the importance of Mongareh Castle, particularly in terms of military position. According to a report from book of Montakhab Al-Tavarikh, on 1393 AD the son of Omar Sheikh (seemingly after Amir Teymour), invaded to this castle and apparently destroyed it (Natanzi; 1957: 450).

This castle includes two detached buildings, which have been place at eastern and western sides of it. The building in western side comprises of approximately square plan with dimensions $(16 \times 12 \mathrm{~m})$ and it totally consists of 5 rooms. The building in eastern side comprises of a rectangular plan with dimensions $(32 \times 16 \mathrm{~m})$ including a central yard and 15 rooms. With respect to architectural style and the utilized materials in space of the castle entirely it seems the building at western side is older and at the front compared to building in eastern side of castle. There are 8 water supplies with various sizes. Generally the used materials in construction of castles are cobble, lime-ash grout, gypsum, and the carved stones.

I removed 12 porcelain artifacts in area of this castle out of which 10 objects coated with mustard color and mustard yellow and white color clay with green, aqua green, and light aqua colored enamels belonged to Islamic middle centuries $\left(12^{\text {th }}\right.$ and $\left.13^{\text {th }} \mathrm{AD}\right)$. Two latter artifacts had white clay with azury blue and white enamel that belonged to $13^{\text {th }}$ and $14^{\text {th }} \mathrm{AD}$ centuries. According to the report from historic texts and Arab geographers and based on description of the discovered porcelains within the building area, it is likely that this castle belongs to Islamic early period and centuries $\left(11^{\text {th }} \mathrm{AD}\right)$ and the later eras and it has been noticed and used the periods after this time. 


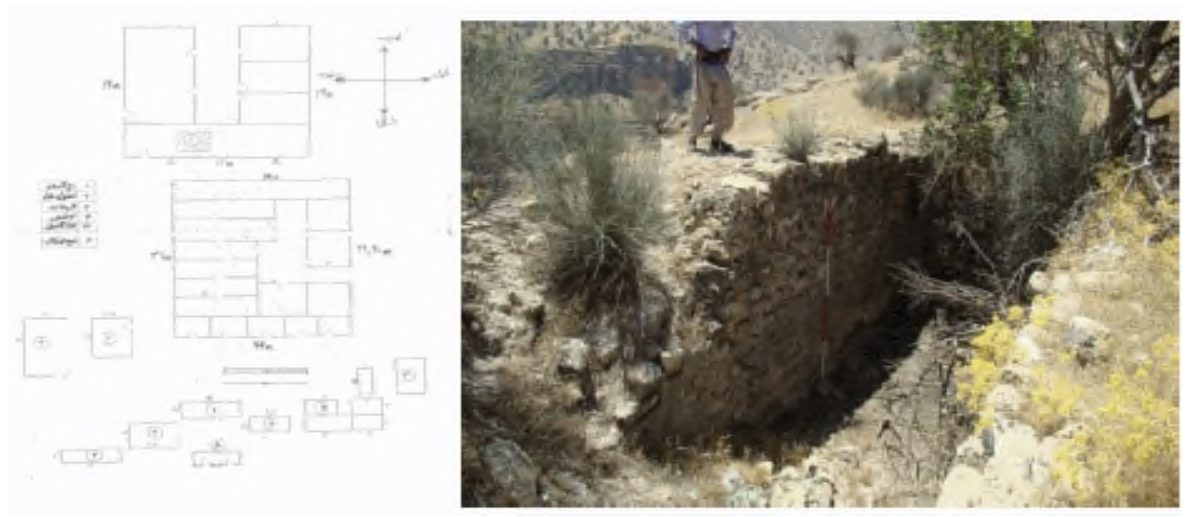

Fig 16: Water course and plan of architectural structure of Mongareh Castle (Source: Author; May 2013)

\section{Conclusion}

There are 9 castles in geographical zone of Andimeshk Town in which two castles were constructed at central district and the remained ones have been built dispersedly in Alvar District. As it mentioned, there are two access routes or roads from Andimeshk to Luristan that Arab geographers as well as domestic and foreign log book writers have dealt with their distance frequently ranged from Shapoorkhast region to Lour and or from Luristan to Khuzestan. The existing castles in the path of Poldokhtar-Andimeshk Road are as follows: Hosseini Castle- Chehar Borji Castle, Gasem Castle and Lour Castle, and other castles, which have been constructed in the access route from Luristan to Mongareh and then to Qilab and then to Andimeshk including Dez Castle (Mongareh), Amir Seif Castle and Chalat Castle. But two Bardel and Couran Castles were built on the eastern piedmont from Alvar District where the regional climate has played essential role in their formation. With respect to the existing archeological evidences, Lour zone on which Andimeshk current texture has been built, was a cultivated city during historical period of Sassanid and geographers have frequently referred to its distance from Shapoorkhast region to Lour. The Lour zone has been again inhabited during Ilkhanate period as well. Unfortunately, no track of fence has been left from Sassanid Lour Castle, but the water transfer system has still exist like water irrigation channels from Sassanid and Ilkhanate periods and it is implied this point. Dez Castle or Mongareh is one of the other castles, which have been important during historical period and its primary space has been probably built in Sassanid period and it has been noticed by Lour Atabakan (Rulers) Dynasty in $1184 \mathrm{AD}$ and it has been utilized as a military citadel in Seljuk period and the next dynasties especially Teimurid era by adding a security fortress along with the historical castle. The aforesaid building has been probably constructed on the same site with Chalat Castle and they were built contemporarily. Sarqala (Amir Seif) Castle is one of the other castles in Islamic period that has been constructed in $12^{\text {th }}$ and 13tht $\mathrm{AD}$ centuries and it is likely this castle to be as headquarter for Rustam Abu Bakr Ibn Mohammad i.e. the second ruler of Luristan Atabakan Dynasty. But of other castles in this region, one could refer to Hosseini Castle, Chehar Borji Castle, Bardel Castle, and Couran (Kooru) Castle, which have been built by rulers of Luristan in Safavid period and they have been noticed and repaired during later period, especially Qajar dynasty.

Architectural structure of castles in Andimeshk has not followed of any certain architectural order and system during historic and Islamic periods and they have been built natively and locally with respect climatic conditions in this region. Overall, the habitat- driven materials have been utilized in 
construction of these monuments such as rubble, fluvial stones, and plaster and lime mortars and sometimes from ash- lime grout.

With respect to placement of castles in these two important access routes among Andimeshk and Luristan, it may be implied that this region is particularly important in terms of political, military, or strategic aspects over historic and Islamic periods.

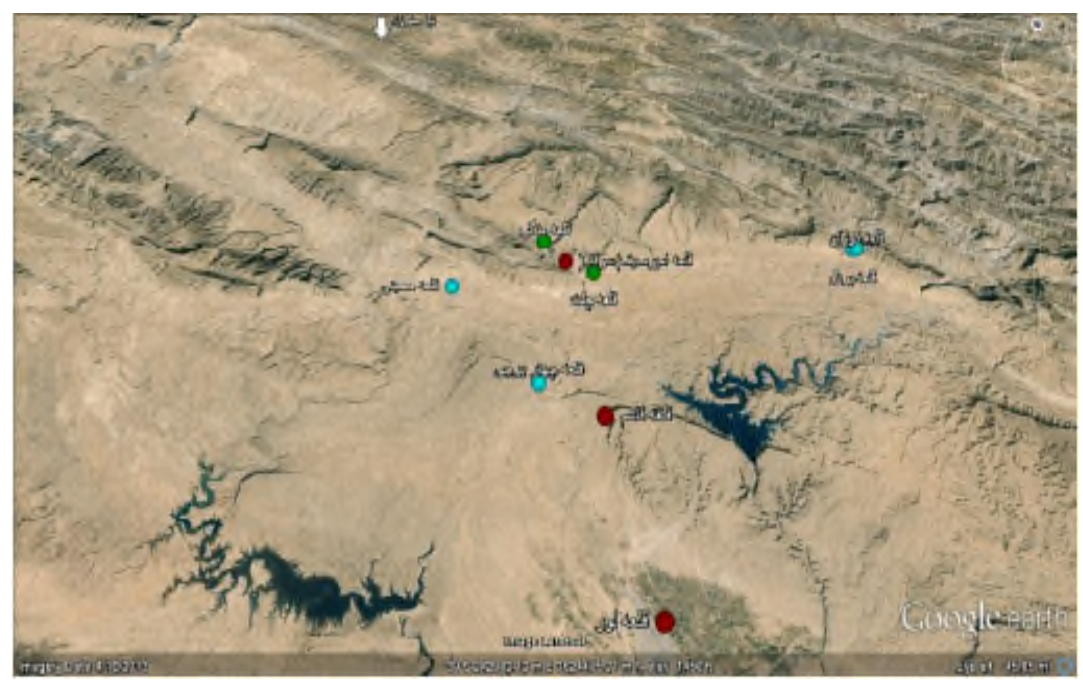

Fig 17: Distribution of castles in Andimeshk situation

(Source: Author; February 2014)

\section{References}

[1] Edmonds, Cecil John (1983), "Notes about Luristan listed in two log books concerning to Luristan", Transl. Baharvand Amanollah \& Bakhtiar Lily, $1^{\text {st }}$ Ed, Tehran: Babak

[2] Imam, Abbas (2009), "Andimeshk and Andimeshk dwellers from the beginning to the end of 1360 Iranian calendar year (1981)", Publication of Khuzestan Studies Foundation

[3] Izadpanah, Hamid (1997), "Luristan archeological and historical monuments", 3 rd vol., $3^{\text {rd }}$ Ed, Publication of cultural monuments and admired figures

[4] Izadmehr, Kooroush \& Uramen, Zahra (2006 \& 2007), "Monuments Registration File", ICHITO Organization, Center of Documents, Andimeshk Town.

[5] Zarei, Mohammad Ebrahim (2013), "The cultural, historical, and archeological monument in Kurdestan Province", Avicenna University, Sobhan No Pub

[6] Shahavand, Kazem (2013), "Archeological investigation and analysis on architectural structures of Andimeshk Town in Islamic Period", MA thesis, Islamic Azad University, Abhar branch

[7] Kiani, Mohammad Yousef (2007), "History of Iranian architecture art during Islamic period", Tehran SAMT Pub

[8] Mustofi, Hamdullah (2010), "Chosen history", (14 AD century), Edited by Navaei Abdul Hossein, Tehran: Amir Kabir Pub

[9] Natanzi, Moeineddin (1957), "Montakhab Al- Tavarikh (The selected histories)", Tehran: Khayyam Pub 
Bulletin de la Société Royale des Sciences de Liège, Vol. 86, special edition, 2017, p. 281 - 293

[10] Hillenbrand, Robert (2001), "Islamic art and architecture", Transl. Ayatollah Zadeh Shirazi, Bagher, Tehran: Rozaneh Pub

[11]Edmonds,c.T.1922, luristan: pish-i-kuh and BalaGariveh. source:the Geographical Journal, vol.59, No.6, (Jun,1922), pp.437-451

[12]Edmonds,c.T.luristan: pish-i-kuh and BalaGariveh, the Geographical Journal, vol.59, No.5, (Jun,1922), pp.335-356 